\title{
Thyroid profile and LDH Isoenzymes as prognostic biomarkers for diabetic and/or obese subjects
}

\author{
Turki Y Johari ${ }^{1}$, Magdy A Ghoneim ${ }^{1,2}$, Said S Moselhy ${ }^{1,3}$
}

1. Department of Biochemistry, Faculty of Science, King Abdulaziz University, Jeddah, Saudi Arabia.

2. Department of Biochemistry, Faculty of Veterinary Medicine, Cairo University, Egypt.

3. Department of Biochemistry, Faculty of Science, Ain Shams University, Egypt.

\begin{abstract}
Background: This study aimed to evaluate the levels of thyroid hormones and lactate dehydrogenase (LDH) isoenzymes in obese and/or diabetic patients.

Subjects and methods: Forty male subjects categorized into four equal groups; group 1: Non obese control subjects, group 2: Subjects suffering from type 2 diabetes mellitus (T2DM), group 3: Obese subjects (BMI $\geq 30 \mathrm{~kg} / \mathrm{m}^{2}$ ) and group 4: Subjects thatwere obese and had type 2 diabetes mellitus (T2DM). Liver, kidney, lipid, thyroid hormones, total LDH and LDH isoenzymes levels were determined.

Results: There was a significant increase of TSH level $(\mathrm{p}<0.001)$ in diabetic group as compared with control group and a highly significant increase of TSH was obtained in obese and obese diabetic groups versus control and diabetic patients. LDH 2 was also highly significantly decreased in obese and obese diabetic groups versus diabetic patients. Percentage of LDH 4 was significantly decreased in both diabetic and obese groups and not significantly changed in obese diabetic patients as compared with the control group. LDH 5 percentage showed very highly significant decrease in diabetic, obese and highly significant decrease in obese diabetic groups when compared with control subjects while it was not significantly changed in obese and obese diabetic groups as compared with diabetic patients.

Conclusion: LDH isozymes can be used as valuable diagnostic markers for metabolic syndrome. This may help to explore the metabolic changes associated with obesity and diabetes complication and following up the complication of these abnormalities.

Keywords: Thyroid profile, lactate dehydrogenase, obesity, diabetes.

DOI: https://dx.doi.org/10.4314/ahs.v18i3.28

Cite as: Jobari TY, Ghoneim MA, Moselby SS. Thyroid profile and LDH isoensymes as prognostic biomarkers for diabetic and/or obese subjects. Afri Health Sci. 2018;18(3): 697-706. https:/ / dx.doi.org/10.4314/abs.v18i3.28
\end{abstract}

\section{Introduction}

Diabetes mellitus, often simply referred to as diabetes, is a group of metabolic diseases in which a person has high blood sugar, either because the body does not produce

\section{Corresponding author:}

Magdy A Ghoneim,

Department of Biochemistry, Faculty of Veterinary

Medicine, Cairo University, Egypt.

Email: m2ghoneim@gmail.com enough insulin, or because cells do not respond to the insulin that is produced. This high blood sugar produces the classical symptoms of polyuria (frequent urination), polydipsia (increased thirst) and polyphagia (increased hunger). The most common forms of diabetes are type 1 diabetes $(5 \%)$, an autoimmune disorder, and type 2 diabetes $(95 \%)$ which is commonly associated with obesity. New criteria for diagnosis of Diabetes mellitus type 2 (T2DM) were published in 1998. These criteria were recommended by the American Diabetes Association (ADA) and the World Health Organization (WHO). In these recommendations, obesity $\geq 20 \%$ over desired 
body weight or body mass index (BMI $\geq 27 \mathrm{~kg} / \mathrm{m}^{2}$ was one of the major risk factors for diabetes mellitus ${ }^{1}$. In healthy individuals, excess fat is stored in adipocytes and only low amounts of triglycerides are maintained in nonadipocytes. In obese individuals, the capacity for adipose tissue to accommodate excess lipids can be exceeded, resulting in the abnormal accumulation of lipids in other tissues. Elevated cellular triglyceride content in muscle, liver and pancreatic islets is associated with physiological dysfunction (lipotoxicity) in those tissues and might be a primary contributing factor for the development of obesity related type 2 diabetes mellitus (T2DM $)^{2}$.

Patients suffering from diabetes mellitus either type 1 (IDDM) or type 2 (NIDDM) are at high risk for diseases whose etiology is related to various factors such as metabolic abnormalities and its enzymes such as lactate Dehydrogenase $(\mathrm{LDH})^{4}$. LDH is an enzyme that catalyzes the conversion of lactate to Pyruvate; an important step in energy production in cells. Some of the organs relatively rich in LDH are the heart, kidney, liver, and muscles ${ }^{3}$. Because this enzyme is actually composed of five different isoenzymes, however, analysis of the different $\mathrm{LDH}$ isoenzyme levels in the blood can help in the diagnosis of some diseases. The five LDH isoenzymes are: LDH-1, LDH-2, LDH-3, LDH-4, and LDH-5. In general, each isoenzyme is used mostly by the cells in a specific tissue. LDH-1 is found mainly in the heart. LDH-2 is primarily associated with the system in the body that defends against infection (reticuloendothelial system). $\mathrm{LDH}-3$ is found in the lungs and other tissues, LDH-4 in the kidney, placenta, and pancreas, and LDH-5 in liver and striated (skeletal) muscle. Normally, levels of LDH-2 are higher than those of the other isoenzymes ${ }^{4}$.

Certain diseases have classic patterns of elevated LDH isoenzyme levels. For example, an LDH-1 level higher than that of LDH-2 is indicative of a heart attack or injury; elevations of LDH-2 and LDH-3 indicate lung injury or disease; elevations of $\mathrm{LDH}-4$ and $\mathrm{LDH}-5$ indicate liver or muscle disease or both. A rise of all $\mathrm{LDH}$ isoenzymes at the same time is diagnostic of injury to multiple organs. For example, a heart attack with congestive heart failure may cause symptoms of lung and liver congestion. Advanced cancer and autoimmune diseases such as lupus can also cause this pattern ${ }^{5}$. In addition, one of the most important diagnostic uses for the $\mathrm{LDH}$ isoenzymes test is in the differential diagnosis of myocardial infarction or heart attack. The total LDH level rises within 24-48 hours after a heart attack, peaks in two to three days, and returns to normal in approximately five to ten days. This pattern is a useful tool for a delayed diagnosis of heart attack ${ }^{6}$.

This study aimed to determine the different levels of some biochemical parameters that are closely related to the problems of human diabetes and obesity. In addition, it aimed to find out the possibility of using lactate Dehydrogenase $(\mathrm{LDH})$ isoenzymes in case of obese and/ or diabetic patients as biomarkers. It was also designed to correlate between the levels of $\mathrm{LDH}$ isoenzymes and other energy-related metabolites that are commonly found among these unhealthy cases.

\section{Subjects and methods Subjects}

This study was approved by the ethics committee of the King Fahad Armed Forces Hospital, Jeddah, Saudi Arabia for sample collection. Written informed consent was obtained from all participants prior to the study. The participants completed an investigator-developed questionnaire on health history. Various demographic variables were assessed, including age in years, history of diabetes, medication and physical activity. All were classified by yes/no based on self-report. The following criteria were established to identify subjects for this investigation.

- Self - identify as Saudis' men.

- 28 - 49 years age.

- Fasting glucose level from 80 to $110 \mathrm{mg} / \mathrm{dl}$ for the normal category and a glucose level $\geq 200 \mathrm{mg} / \mathrm{dl}$ for diabetic category.

- Body mass index (BMI) of 18.5 to $24.9 \mathrm{~kg} / \mathrm{m}^{2}$ for the normal weight category and a BMI $\geq 30 \mathrm{~kg} / \mathrm{m}^{2}$ for obese category.

\section{Study design}

This study was conducted on forty male subjects admitted to a clinical laboratory of the King Fahad Armed Forces Hospital and diagnosed by professional physicians. Samples were categorized into four equal groups according to case history and clinical examination as follows:

Group 1: Non obese-non diabetic control subjects that were not suffering from any pathological condition (BMI 
$\left.\leq 21.6 \mathrm{~kg} / \mathrm{m}^{2}\right)$. Group 2: Subjects that are suffering from diabetes mellitus type 2 (DM 2). Group 3: Subjects that from obesity (BMI $\geq 30 \mathrm{~kg} / \mathrm{m}^{2}$ ). Group 4: Subjects that were obese and had type 2 diabetes mellitus.

\section{Anthropometric assessment}

Height and weight measurement were obtained from each participant by the same investigator. Subjects were required to remove shoes and heavy outer garments before the measurements of height and weight. Body Mass Index (BMI) was calculated by the equation BMI = Weight in $\mathrm{kg} /$ height in $\mathrm{m}^{2}$ as mentioned ${ }^{7}$.

\section{Sample collection}

After 10-12 hours of overnight fasting, about five milliliters of blood were drawn from each participant by using standard vein puncture technique in plain vaccutainer tubes for serum separation. The tubes were left at room temperature for about 30 minutes for blood clotting. The serum was separated by centrifugation at $2000 \mathrm{rpm}$ for 10 minutes. The serum was stored at $-20^{\circ} \mathrm{C}$ till analysis.

\section{Biochemical analysis}

\section{Determination of Serum Glucose Level}

GLU reagent (Siemens kit No. DF39A), when used in conjunction with The Dimension $® \mathrm{X}$ pand plus integrated chemistry system, is intended for quantitative determination of glucose concentration in human serum according to ${ }^{8}$.

\section{Determination of Serum total activity of Lactate Dehydrogenase}

The LDH (lactate dehydrogenase) determination method (Siemens kit No. DF54) uses as a substrate L-lactate buffered at a $\mathrm{pH}$ of 9.4. Lactate dehydrogenase oxidizes the substrate in the presence of NAD+ to yield pyruvate and NADH which absorbs colour at $340 \mathrm{~nm}$. Lactate dehydrogenase activity is measured as a rate reaction at $340 / 700 \mathrm{~nm}$, proportional to the amount of lactate dehydrogenase in the sample.

\section{Determination of serum lipid profile}

Cholesterol reagent (Siemens kit No. DF27), when used in conjunction with The Dimension $\mathbb{R}$ X pand plus integrated chemistry system, is intended for quantitative determination of cholesterol concentration in human serum ${ }^{8}$.
Quantitative determination of HDL cholesterol (HDL-c) in serum was done according to the time end point methods ${ }^{9}$, by using Siemens kit No. DF48B. The method for LDL determination is in a two reagent format and depends on the properties of detergent 1 , which solubilizes only non- LDL particles in Siemens kit No. DF131A? The triglycerides determination method is based on an enzymatic procedure ${ }^{10}$, using Siemens kit No. DF69.

\section{Determination of serum kidney function tests}

Blood urea nitrogen (BUN) was determined by using Siemens kit No. DF21 based on the bichromatic (340, 383 $\mathrm{nm})$ rate technique ${ }^{11}$.

In the presence of a strong base such as $\mathrm{NaOH}$, picrate reacts with creatinine to form a red chromophore (Siemens kit No. DF33A). The rate of increasing absorbance at $510 \mathrm{~nm}$ due to the formation of this chromophore is directly proportional to the creatinine concentration in the sample and is measured using a bichromatic $(510,600$ $\mathrm{nm})$ rate technique ${ }^{12}$.

\section{Determination of serum liver function tests}

Alanine aminotransferase (ALT) and Aspartate aminotransferase (AST) activities were determined using a bichromatic $(340,700 \mathrm{~nm})$ rate technique ${ }^{13}$.

\section{Evaluation of thyroid function profile}

The architect TSH, FT3 and FT4 assay is a Chemiluminescent Microparticle Immunoassay (CMIA) for the quantitative determination of human thyroid stimulating hormone, Free Triiodothyronine and Free Thyroxine in human serum. Evaluation and calculation of the concentration of the antigen are carried out by means of calibration curve that was established using standards of known antigen concentration ${ }^{14}$.

\section{Electrophoretic pattern of lactate Dehydrogenase Isoenzymes}

Identification of the LDH isoenzymes performed by electrophoresis depends on fluorescence of NADH produced by the enzyme ${ }^{15}$. At the $\mathrm{pH}$ used $\left(8.6\right.$ at $\left.20^{\circ} \mathrm{C}\right)$, enzymes LDH-1 to LDH-4 migrate towards the anode and LDH-5 moves towards the cathode on the agarose film. The LDH isoenzymes are detected after a short incubation with a liquid overlay containing L-lactate and NAD. The reaction produces $\mathrm{NADH}$, which fluoresces at al- 
kaline $\mathrm{pH}$ after excitation by light at about $360 \mathrm{~nm}$. The isoenzymes are quantified by the relative proportion of fluorescence generated by each isoenzyme band.

\section{Statistical analysis}

Statistical analyses were performed by using the Statistical Package for Social Sciences (SPSS) version 20.0 (SPSS Inc., Chicago, IL, USA). Categorical variables were presented as frequencies. Independent samples T-test was used to compare between continuous variable and groups. The $\mathrm{P}$ value at $<0.05$ was considered as significant. Persons correlation was determined between each single parameter and others.

\section{Results}

Table (1) showed that there were no significant changes in the levels of serum urea and creatinine in diabetic, obese and obese diabetic groups as compared with the control group. In addition, there were no significant changes in these parameters found between obese and diabetic obese versus diabetic patients. However, serum ALT activity was significantly elevated in obese $(\mathrm{P} \leq 0.01)$ and obese diabetic $(\mathrm{P} \leq 0.01)$ groups when compared with control subjects. In addition, there was a significant increase in ALT activity of obese $(\mathrm{P} \leq 0.05)$ and obese diabetic $(\mathrm{P} \leq 0.05)$ groups versus diabetic patients. On the other hand, serum AST activity was not significantly changed in all groups.

\section{Table 1. Serum kidney and liver function tests in different groups}

\begin{tabular}{|c|c|c|c|c|}
\hline $\begin{array}{r}\text { Groups } \\
\text { Parameters }\end{array}$ & $\begin{array}{l}\text { Group I } \\
(\mathrm{N}: 10)\end{array}$ & $\begin{array}{l}\text { Group II } \\
(\mathrm{N}: 10)\end{array}$ & $\begin{array}{l}\text { Group III } \\
(\mathrm{N}: 10)\end{array}$ & $\begin{array}{l}\text { Group IV } \\
(\mathrm{N}: 10)\end{array}$ \\
\hline $\begin{array}{l}\text { Urea }(\mathrm{mg} / \mathrm{dl}) \\
\text { Mean } \pm \text { SD } \\
\mathbf{P} \\
\mathbf{P}^{*}\end{array}$ & $\begin{array}{l}13.29 \pm 1.8 \\
-- \\
--\end{array}$ & $\begin{array}{l}15.10 \pm 3.0 \\
\text { N.S } \\
--\end{array}$ & $\begin{array}{l}19.38 \pm 2.7 \\
\text { N.S } \\
\text { N.S }\end{array}$ & $\begin{array}{l}17.18 \pm 2.7 \\
\text { N.S } \\
\text { N.S }\end{array}$ \\
\hline $\begin{array}{l}\text { Creatinine }(\mathrm{mg} / \mathrm{dl}) \\
\text { Mean } \pm \mathrm{SD} \\
\mathbf{P} \\
\mathbf{P}^{*}\end{array}$ & $\begin{array}{ll}1.01 & \pm 0.1 \\
-- & \\
--- & \end{array}$ & $\begin{array}{l}1.04 \pm 0.1 \\
\text { N.S } \\
---\end{array}$ & $\begin{array}{l}0.95 \pm 0.1 \\
\text { N.S } \\
\text { N.S }\end{array}$ & $\begin{array}{l}0.90 \pm 0.2 \\
\text { N.S } \\
\text { N.S }\end{array}$ \\
\hline $\begin{array}{l}\text { ALT ( U/L ) } \\
\text { Mean } \pm \text { SD } \\
\mathbf{P} \\
\mathbf{P}^{*}\end{array}$ & $\begin{array}{l}34.57 \pm 4.4 \\
--- \\
--\end{array}$ & $\begin{array}{l}42.30 \pm 8.2 \\
\text { N.S } \\
---\end{array}$ & $\begin{array}{l}63.0 \pm 9.7 \\
<0.01 \\
<0.05\end{array}$ & $\begin{array}{l}59.91 \pm 8.2 \\
<0.01 \\
<0.05\end{array}$ \\
\hline $\begin{array}{l}\text { AST (U/L) } \\
\text { Mean } \pm \text { SD } \\
\text { P } \\
\text { P }^{*}\end{array}$ & $\begin{array}{l}17.71 \pm 1.9 \\
--- \\
---\end{array}$ & $\begin{array}{l}19.43 \pm 3.1 \\
\text { N.S } \\
----\end{array}$ & $\begin{array}{l}20.75 \pm 3.8 \\
\text { N.S } \\
\text { N.S }\end{array}$ & $\begin{array}{l}22.27 \pm 2.5 \\
\text { N.S } \\
\text { N.S }\end{array}$ \\
\hline
\end{tabular}

Table (2) demonstrated a significant increase in the mean serum level of triglycerides in diabetic $(\mathrm{P} \leq 0.05)$, obese $(\mathrm{P} \leq 0.01)$ and obese diabetic $(\mathrm{P} \leq 0.001)$ groups when compared with the control group. Triglycerides level of obese diabetic $(\mathrm{P} \leq 0.05)$ and obese $(\mathrm{P} \leq 0.05)$ subjects was also significantly elevated versus diabetic patients. The changes of mean level of total cholesterol, HDL-c and LDL-c were not significant in diabetic, obese and diabetic obese groups when compared with the control normal group and also there were no significant changes when compared with diabetic patients. 
Table 2. Serum lipid parameters in different groups

\begin{tabular}{|c|c|c|c|c|}
\hline $\begin{array}{r}\text { Groups } \\
\text { Parameters }\end{array}$ & $\begin{array}{l}\text { Group I } \\
\text { (N:10) }\end{array}$ & $\begin{array}{l}\text { Group II } \\
\text { (N:10) }\end{array}$ & $\begin{array}{l}\text { Group III } \\
\text { (N:10) }\end{array}$ & $\begin{array}{l}\text { GroupIV } \\
(\mathrm{N}: 10)\end{array}$ \\
\hline $\begin{array}{l}\text { Triglycerides }(\mathrm{mg} / \mathrm{dl}) \\
\text { Mean } \pm \text { SD } \\
\mathbf{P} \\
\mathbf{P}^{*}\end{array}$ & $\begin{array}{l}135.86 \pm 10.2 \\
--- \\
---\end{array}$ & $\begin{array}{l}165.70 \pm 14.2 \\
<0.05 \\
---\end{array}$ & $\begin{array}{l}181.50 \pm 13.0 \\
<0.01 \\
<0.05\end{array}$ & $\begin{array}{l}199.0 \pm 11.6 \\
<0.001 \\
<0.05\end{array}$ \\
\hline $\begin{array}{l}\text { Cholesterol }(\mathrm{mg} / \mathrm{dl}) \\
\text { Mean } \pm \text { SD } \\
\mathbf{P} \\
\mathbf{P}^{*} \\
\end{array}$ & $\begin{array}{l}188.14 \pm 22.7 \\
--- \\
--\end{array}$ & $\begin{array}{l}207.50 \pm 27.2 \\
\text { N.S } \\
--\end{array}$ & $\begin{array}{l}181.0 \pm 21.2 \\
\text { N.S } \\
\text { N.S }\end{array}$ & $\begin{array}{l}199.27 \pm 23.6 \\
\text { N.S } \\
\text { N.S }\end{array}$ \\
\hline $\begin{array}{l}\text { HDL- c }(\mathrm{mg} / \mathrm{dl}) \\
\text { Mean } \pm \text { SD } \\
\mathbf{P} \\
\mathbf{P}^{*} \\
\end{array}$ & $\begin{array}{l}41.71 \pm 10.1 \\
--- \\
---\end{array}$ & $\begin{array}{l}49.10 \pm 9.35 \\
\text { N.S } \\
---\end{array}$ & $\begin{array}{l}40.0 \pm 3.97 \\
\text { N.S } \\
\text { N.S }\end{array}$ & $\begin{array}{l}39.27 \pm 8.4 \\
\text { N.S } \\
\text { N.S }\end{array}$ \\
\hline $\begin{array}{l}\text { LDL- c }(\mathrm{mg} / \mathrm{dl}) \\
\text { Mean } \pm \mathrm{SD} \\
\mathbf{P} \\
\mathbf{P}^{*}\end{array}$ & $\begin{array}{l}125.0 \pm 15.1 \\
--- \\
---\end{array}$ & $\begin{array}{l}133.20 \pm 19.4 \\
\text { N.S } \\
---\end{array}$ & $\begin{array}{l}126.88 \pm 17.0 \\
\text { N.S } \\
\text { N.S }\end{array}$ & $\begin{array}{l}130.36 \pm 16.1 \\
\text { N.S } \\
\text { N.S }\end{array}$ \\
\hline
\end{tabular}

Table (3) showed the averages of selected thyroid hormones level in different groups under study. There was a significant increase of TSH level in diabetic group (P $\leq$ 0.05) as compared with control subjects and very highly significant increase of TSH in obese $(\mathrm{P} \leq 0.001)$ and obese diabetic $(\mathrm{P} \leq 0.001)$ groups versus control and diabetic patients. On the other hand, the changes of FT3 level were not significant in all groups when compared with control subjects and diabetic patients. In addition, FT4 levels showed different significant changes in obese and diabetic obese groups when compared with control and diabetic subjects. There was a highly significant increase of FT4 in diabetic subjects $(\mathrm{P} \leq 0.01)$ versus the control group while there was a highly significant decrease in obese $(\mathrm{P} \leq 0.01)$ and obese diabetic $(\mathrm{P} \leq 0.01)$ groups versus diabetic patients. 
Table 3. Serum thyroid hormones (TSH, FT3 and FT4) in studied groups

\begin{tabular}{|c|c|c|c|c|}
\hline $\begin{array}{c}\text { Groups } \\
\text { Parameters }\end{array}$ & $\begin{array}{l}\text { Group I } \\
\text { (N:10) }\end{array}$ & $\begin{array}{l}\text { Group II } \\
(\mathrm{N}: 10)\end{array}$ & $\begin{array}{l}\text { Group III } \\
(\mathrm{N}: 10)\end{array}$ & $\begin{array}{l}\text { Group IV } \\
(\mathrm{N}: 10)\end{array}$ \\
\hline $\begin{array}{l}\text { TSH }(\mathrm{uUL} / \mathrm{ml}) \\
\text { Mean } \pm \text { SD } \\
\mathbf{P} \\
\mathbf{P}^{*}\end{array}$ & $\begin{array}{l}1.10 \pm 0.40 \\
--- \\
---\end{array}$ & $\begin{array}{l}1.49 \pm 0.40 \\
<0.05 \\
---\end{array}$ & $\begin{array}{l}3.90 \pm 0.29 \\
<0.001 \\
<0.001\end{array}$ & $\begin{array}{l}4.06 \pm 0.23 \\
<0.001 \\
<0.001\end{array}$ \\
\hline $\begin{array}{l}\text { FT3 }(\mathrm{pmol} / \mathrm{l}) \\
\text { Mean } \pm \text { SD } \\
\text { P } \\
\text { P }^{*} \\
\end{array}$ & $\begin{array}{l}5.05 \pm 0.60 \\
--- \\
---\end{array}$ & $\begin{array}{l}4.89 \pm 0.70 \\
\text { N.S } \\
--- \\
\end{array}$ & $\begin{array}{l}5.29 \pm 0.70 \\
\text { N.S } \\
\text { N.S } \\
\end{array}$ & $\begin{array}{l}5.09 \pm 0.60 \\
\text { N.S } \\
\text { N.S }\end{array}$ \\
\hline $\begin{array}{l}\text { FT4 }(\mathrm{ng} / \mathrm{dl}) \\
\text { Mean } \pm \text { SD } \\
\text { P } \\
\text { P }^{*}\end{array}$ & $\begin{array}{l}14.22 \pm 1.5 \\
--- \\
---\end{array}$ & $\begin{array}{l}17.21 \pm 3.2 \\
<0.01 \\
---\end{array}$ & $\begin{array}{l}14.27 \pm 3.6 \\
\text { N.S } \\
<0.01\end{array}$ & $\begin{array}{l}14.06 \pm 2.5 \\
\text { N.S } \\
<0.01\end{array}$ \\
\hline
\end{tabular}

$P$ value: diabetic, obese and obese diabetic versus control group

$\mathrm{P}^{*}$ : obese and obese diabetic versus diabetic group

N.S: Non Significant, $\mathrm{P}<0.05$ : Significant, $\mathrm{P}<0.01$ : Highly significant, $\mathrm{P}<0.001$ : Very highly significant

Results of the present study listed in table (4) revealed that serum glucose level in diabetic $(\mathrm{P} \leq 0.001)$ and obese diabetic $(\mathrm{P} \leq 0.001)$ groups was very significantly higher than that in control subjects and in obese ones when compared with diabetic patients. On the other hand, there were no significant changes in both lactic acid and LDH activity in different groups as compared with control and diabetes subjects.

Table 4. Serum levels of Glucose, Lactate and Total Lactate Dehydrogenase activity in different experimental groups

\begin{tabular}{|c|c|c|c|c|}
\hline $\begin{array}{c}\text { Groups } \\
\text { Parameters }\end{array}$ & $\begin{array}{l}\text { Group I } \\
(\mathrm{N}: 10)\end{array}$ & $\begin{array}{l}\text { Group II } \\
(\mathrm{N}: 10)\end{array}$ & $\begin{array}{l}\text { Group III } \\
(\mathrm{N}: 10)\end{array}$ & $\begin{array}{l}\text { Group IV } \\
(\mathrm{N}: 10)\end{array}$ \\
\hline $\begin{array}{l}\text { Glucose }(\mathrm{mg} / \mathrm{dl}) \\
\text { Mean } \pm \mathrm{SD} \\
\mathbf{P} \\
\mathbf{P}^{*}\end{array}$ & $\begin{array}{l}90.14 \pm 29.6 \\
--- \\
---\end{array}$ & $\begin{array}{l}215.10 \pm 10.2 \\
<0.001 \\
-----\end{array}$ & $\begin{array}{l}99.50 \pm 8.6 \\
\text { N.S } \\
<0.001\end{array}$ & $\begin{array}{l}220.27 \pm 74.5 \\
<0.001 \\
\text { N.S }\end{array}$ \\
\hline $\begin{array}{l}\text { Lactic Acid }(\mathrm{mmol} / \mathrm{L}) \\
\text { Mean } \pm \text { SD } \\
\mathbf{P} \\
\mathbf{P}^{*}\end{array}$ & $\begin{array}{l}2.21 \pm 0.4 \\
--- \\
---\end{array}$ & $\begin{array}{l}2.42 \pm 0.9 \\
\text { N.S } \\
---\end{array}$ & $\begin{array}{l}2.59 \pm 0.7 \\
\text { N.S } \\
\text { N.S }\end{array}$ & $\begin{array}{l}2.77 \pm 1.2 \\
\text { N.S } \\
\text { N.S }\end{array}$ \\
\hline $\begin{array}{l}\text { LDH (U/L) } \\
\text { Mean } \pm \text { SD } \\
\text { P } \\
\mathbf{P}^{*}\end{array}$ & $\begin{array}{l}191.14 \pm 31.1 \\
---\end{array}$ & $\begin{array}{l}182.90 \pm 27.2 \\
\text { N.S } \\
---\end{array}$ & $\begin{array}{l}196.13 \pm 26.9 \\
\text { N.S } \\
\text { N.S }\end{array}$ & $\begin{array}{l}186.36 \pm 29.5 \\
\text { N.S } \\
\text { N.S }\end{array}$ \\
\hline
\end{tabular}


The percentage of different $\mathrm{LDH}$ isoenzymes level obtained for variable groups (table 5) showed between significant and non-significant changes as described in the following details: Percentage of LDH 1 was significantly decreased in diabetic $(\mathrm{P} \leq 0.01)$, obese $(\mathrm{P} \leq 0.01)$ and obese diabetic $(\mathrm{P} \leq 0.01)$ groups as compared with control subjects, also there was a significant decrease in obese $(\mathrm{P} \leq 0.01)$ and obese diabetic $(\mathrm{P} \leq 0.01)$ groups versus diabetic patients.

LDH 2 percentage was significantly decreased in diabetic group ( $\mathrm{P} \leq 0.05)$, highly significantly decreased in both obese $(\mathrm{P} \leq 0.01)$ and obese diabetic $(\mathrm{P} \leq 0.01)$ groups when compared with the control one. LDH 2 was also highly significantly decreased in obese $(\mathrm{P} \leq 0.01)$ and obese diabetic $(\mathrm{P} \leq 0.01)$ groups versus diabetic patients. LDH3 mean percentage was not significantly changed in diabetic, obese and obese diabetic groups as compared with the control one and also not significantly changed in obese and obese diabetic groups versus diabetic patients. Percentage of LDH 4 was significantly decreased in both diabetic $(\mathrm{P} \leq 0.05)$ and obese $(\mathrm{P} \leq 0.01)$ groups and did not significantly change in obese diabetic patients as compared with the control group. The obese diabetic LDH4 percent was significantly increased $(\mathrm{P} \leq 0.01)$ while the obese group LDH4 percentage was not significantly changed as in diabetic patients. LDH 5 percentage showed very highly significant decrease $(\mathrm{P} \leq 0.001)$ in diabetic, obese $(\mathrm{P} \leq 0.001)$ and highly significant decrease in obese diabetic $(\mathrm{P} \leq 0.01)$ groups when compared with control subjects while it was not significantly changed in obese and obese diabetic groups as compared with diabetic patients.

Table 5. Percentage of serum LDH Isoenzymes in different groups

\begin{tabular}{|c|c|c|c|c|}
\hline $\begin{array}{c}\text { Groups } \\
\text { Parameters }\end{array}$ & $\begin{array}{l}\text { Group I } \\
(\mathrm{N}: 10)\end{array}$ & $\begin{array}{l}\text { Group II } \\
(\mathrm{N}: 10)\end{array}$ & $\begin{array}{l}\text { Group III } \\
(\mathrm{N}: 10)\end{array}$ & $\begin{array}{l}\text { Group IV } \\
(\mathrm{N}: 10)\end{array}$ \\
\hline $\begin{array}{l}\text { LDH } 1(\%) \\
\text { Mean } \pm \text { SD } \\
\text { P } \\
\mathbf{P}^{*}\end{array}$ & $\begin{array}{l}25.38 \pm 3.3 \\
--- \\
---\end{array}$ & $\begin{array}{l}22.83 \pm 4.1 \\
<0.01 \\
---\end{array}$ & $\begin{array}{l}21.03 \pm 1.6 \\
<0.01 \\
<0.01\end{array}$ & $\begin{array}{l}21.58 \pm 1.8 \\
<0.01 \\
<0.01\end{array}$ \\
\hline $\begin{array}{l}\text { LDH } 2(\%) \\
\text { Mean } \pm \text { SD } \\
\mathbf{P} \\
\mathbf{P}^{*} \\
\end{array}$ & $\begin{array}{l}36.90 \pm 3.05 \\
--- \\
---\end{array}$ & $\begin{array}{l}35.70 \pm 2.1 \\
<0.05 \\
---\end{array}$ & $\begin{array}{l}32.60 \pm 4.29 \\
<0.01 \\
<0.01\end{array}$ & $\begin{array}{l}31.58 \pm 1.8 \\
<0.01 \\
<0.01 \\
\end{array}$ \\
\hline $\begin{array}{l}\text { LDH } 3(\%) \\
\text { Mean } \pm \text { SD } \\
\mathbf{P} \\
\mathbf{P}^{*} \\
\end{array}$ & $\begin{array}{l}22.08 \pm 1.6 \\
--- \\
---\end{array}$ & $\begin{array}{l}22.90 \pm 1.6 \\
\text { N.S } \\
--- \\
\end{array}$ & $\begin{array}{l}23.18 \pm 2.1 \\
\text { N.S } \\
\text { N.S }\end{array}$ & $\begin{array}{l}23.88 \pm 1.9 \\
\text { N.S } \\
\text { N.S }\end{array}$ \\
\hline $\begin{array}{l}\text { LDH } 4(\%) \\
\text { Mean } \pm \text { SD } \\
\mathbf{P} \\
\mathbf{P}^{*}\end{array}$ & $\begin{array}{l}11.35 \pm 2.1 \\
--- \\
---\end{array}$ & $\begin{array}{l}8.37 \pm 0.3 \\
<0.05 \\
---\end{array}$ & $\begin{array}{l}7.93 \pm 1.3 \\
<0.01 \\
\text { N.S }\end{array}$ & $\begin{array}{l}10.63 \pm 1.5 \\
\text { N.S } \\
<0.01\end{array}$ \\
\hline $\begin{array}{l}\text { LDH } 5(\%) \\
\text { Mean } \pm \text { SD } \\
\mathbf{P} \\
\mathbf{P}^{*}\end{array}$ & $\begin{array}{l}10.40 \pm 1.6 \\
--- \\
---\end{array}$ & $\begin{array}{l}5.77 \pm 0.2 \\
<0.001 \\
---\end{array}$ & $\begin{array}{l}6.3 \pm 1.9 \\
<0.001 \\
\text { N.S }\end{array}$ & $\begin{array}{l}7.50 \pm 0.2 \\
<0.01 \\
\text { N.S }\end{array}$ \\
\hline
\end{tabular}

P value: diabetic, obese and obese diabetic versus control group

$\mathrm{P}^{*}$ : obese and obese diabetic versus diabetic group

N.S: Non Significant, $\mathrm{P}<0.05$ : Significant, $\mathrm{P}<0.01$ : Highly significant,

$\mathrm{P}<0.001$ : Very highly significant 


\section{Discussion}

This study was designed to find out the possibility of using lactate dehydrogenase $(\mathrm{LDH})$ isoenzymes as biomarkers in case of obese and/or diabetic patients and to correlate between the levels of $\mathrm{LDH}$ isoenzymes and other energy-related metabolites in these patients. The importance of continuous studying of diabetes is a must where the incidence of T2DM has been increasing rapidly in the past 2 decades and is expected to increase further ${ }^{16}$. It was estimated that the number of adults with diabetes will be more than double from an estimated 143 million in 1997 to 300 million by $2025^{17}$. T2DM is accompanied notably by a high prevalence of associated disorders; such as hypertension; atherogenesis; metabolic syndrome; myocardial infarction (MI); retinopathy (Rt); nephropathy $(\mathrm{Np})$; neuropathy $(\mathrm{Nu})$; vascular diseases (cardiac; cerebral and peripheral); and cardiovascular disease (CVD); which lead to significantly high morbidity and mortality ${ }^{18}$.

According to International Obesity Task Force (IOTF); Greece showed the highest prevalence of both overweight and obese women (74\%) and second highest in case of men (72\%). Saudi Arabia, a Middle Eastern country with a population around 23 million, has undergone significant economic and cultural changes over the past thirty years. Approximately $60 \%$ of population are urbanized and have adopted lifestyle reflecting their physical activity and diet. The prevalence of obesity has increased dramatically in Saudi Arabia and has reached epidemic proportions especially among females ${ }^{19}$. Obesity can be regarded as a major health problem among the Saudi population. A previous study indicated that in overall population $13.05 \%$ males and $20.26 \%$ females were obese. The inter-relationship between obesity and insulin resistance; dyslipidemia and hypertension may contribute to cardiovascular risk; but the extent is not known ${ }^{20}$. Insulin affects mammalian lipid metabolism by stimulating synthesis of fatty acid in liver; adipose tissue and intestine. Since insulin is also known to increase cholesterol synthesis. Therefore, in the present study, liver, kidney, lipid, and thyroid profiles in addition to lactate dehydrogenase activity and fractionation of its isoenzymes were evaluated in diabetic, obese and obese diabetic patients as compared control normal subjects.

In this study, liver and kidney profiles were measured for the different groups and a significant increase in serum ALT activity in obese and obese diabetic patients was found. A number of observational studies have suggested that abnormal liver function test is associated with obesity, insulin resistance, and metabolic syndromes ${ }^{21}$. Several prospective studies have also shown that high levels of ALT and GGT are independently associated with increased risk for incident metabolic syndrome and diabetes $^{22}$. In non-diabetic subjects, some studies suggested that GGT might be a stronger predictor of development of type 2 diabetes than AST or ALT while others have suggested that ALT is the only predictor ${ }^{20}$.

Many studies have investigated the association of intramyocellular lipid stores as triglycerides with insulin resistance, showing either a positive correlation ${ }^{22}$ or no correlation $^{23}$. In fact, no direct link has been established between insulin sensitivity and intramyocellular triglycerides. The available studies on the intramyocellular triglycerides accumulation under different insulin-resistance states (obesity and diabetes) have produced controversial results. No difference in intramyocellular triglycerides between diabetic subjects and body mass index (BMI)-matched controls. On the contrary it was reported almost 2-fold higher levels of intramyocellular triglycerides in diabetic obese subjects compared with nondiabetic obese subjects. There are some data indicating that intramyocellular lipids may be differentially regulated in diabetes and obesity. For example, diet-induced weight loss has resulted in a significant decrease in intramyocellular triglycerides in diabetic obese subjects, but not in obese normoglycemic subjects ${ }^{24}$.

Consequently, the role of intramyocellular triglycerides in the pathophysiology of diabetes remains unclear. Our results showed that triglycerides were increased significantly in diabetic, obese and obese diabetic compared with control subjects, and also showed a highly significant increase in obese and obese diabetic groups versus diabetic patients.

The influence of other endocrine and non-endocrine organs other than the pancreas on diabetes mellitus is documented. Occasionally other endocrine disorders such as abnormal thyroid hormones levels are found in diabetes ${ }^{25}$. The major alterations in thyroid hormones are a reduction 
in the TSH stimulation of the thyroid gland, probably caused by central hypothyroidism, and in the peripheral generation of T3 from T4. In chemically induced diabetic animals, the alterations in the hypothalamo-pituitary-thyroid axis in diabetic rats are numerous; hypothalamic and plasma TRH, pituitary and plasma TSH, as well as TSH secretion rate are reduced, and the TSH response to TRH is decreased despite normal peripheral TSH metabolism. T3 and T4 production and iodide uptake by the thyroid are diminished.

There are also important structural changes in the thyroid and pituitary glands that are accompanied by marked alterations in their secretory activity. In addition, T4 deiodination to T3 in peripheral tissues is decreased. The physiological and biochemical inter-relationship between insulin and the influence of both insulin and iodothyronines on the metabolism of carbohydrates, proteins and lipids are recorded ${ }^{26}$. Such records indicated that iodothyronines are insulin antagonist with high levels being diabetogenic while absence of the hormone inhibits the development of diabetes. The abnormal thyroid hormones levels may be the outcome of the various medications the diabetics were receiving. For example, it is known that insulin; an anabolic hormone enhances the levels of FT4 while it suppresses the levels of T3 by inhibiting hepatic conversion of T4 to T3. On the other hand, some of the oral hypoglycemic agents such as the phenylthioureas are known to suppress the levels of FT4 and $\mathrm{T} 4$, while causing raised levels of $\mathrm{TSH}^{26}$. In the current study, we confirmed that the TSH was significantly increased in diabetic and obese diabetic as compared with control subjects and also increased in obese diabetic versus obese diabetic patients.

Lactate dehydrogenase (LDH) is an enzyme of special interest due to its key position in anaerobic metabolic pathways. In the current study, LDH activities showed no significant change in diabetic and obese diabetic groups as compared with control subjects. Also, no significant change appeared in obese and obese diabetic as compared with diabetic patients. In agreement with our study, Kamble et al., ${ }^{27}$, found that mild diabetes mellitus has no effect on $\mathrm{LDH}$, but raised plasma levels of $\mathrm{LDH}$ in severe diabetes mellitus was found to be highly significant which indicated the mild diabetic patients in our study.
In the present study, LDH isoenzymes activities showed different significant changes as compared with control and diabetic subjects. LDH 1, 2, 4 and 5 were significantly decreased when compared with control and diabetic patients and LDH 3 was not significantly changed in the different compared groups. In contrast to our study, Vi$\mathrm{zir}^{28}$, showed that the shifts in the LDH activity proved to be characteristic of all the degrees of diabetes severity, and were expressed in a significant elevation of total $\mathrm{LDH}, \mathrm{LDH} 4,5$ activities and a decrease of LDH1, 2 activities in comparison with healthy individuals. No change of LDH3 activity was noted in mild forms of diabetes. But in severe form the isoenzymatic spectrum was mostly changed on account of LDH3 hyperfermentemia. In mild form of diabetes, it approached control values.

\section{Conclusion}

Levels of LDH isoenzymes were correlated with endocrine and biochemical parameters as TSH, FT4, ALT, triglycerides and glucose in different studied groups. This will help to explore the changes associated with obesity and diabetes complication and to help in development of a management program to control complication of these abnormalities.

\section{Conflict of interest}

There is no conflict of interest concerning this manuscript.

\section{References}

1. Alberti KG, Zimmet PZ. Definition, diagnosis and classification of diabetes mellitus and its complications. Part I: diagnosis and classification of diabetes mellitus provisional report of WHO consultation. Diabet. Med.; (1998) 15: 539-553.

2. Unger, R.H. Lipotoxic diseases. Annu. Rev. Med. (2002). 53: 319-336.

3. Arai, T., Kusaba, A., Takeguchi, A., Tanaka, Y., Ozawa, T., Yoshida, T., Sako, T.,Hayashi, T. and Blair, H. Comparison of plasma metabolite concentrations and peripheral leukocyte enzyme activities in sheep fed on different diets in New Zealand and Japan. Vet. Res. Commun. (2007). 31: 681-684.

4. Kahn, S. E., Hull, R. L., \& Utzschneider, K. M. Mechanisms linking obesity to insulin resistance and type 2 diabetes. Nature, (2006). 444: 840-846. 
5. Joseph J, Badrinath P, Basran GS, Sahn SA. Is the pleural fluid transudate or exudate? A revisit of the diagnosticcriteria. Thorax, (2001). 56 (11): 867-70.

6. Joseph J, Badrinath P, Basran GS, Sahn SA. Is albumin gradient or fluid to serum albumin ratio better than the pleural fluid lactate dehydroginase in the diagnostic of separation of pleural effusion?. BMC Pulm Med. 2002 Mar 22;2:1.

7. Garrow, J, S and Webster, J. Quetelets index (W/4) as a measure of fatness. Int. J obesity, (1985) 9: 147-153.

8. Roeschlau, P., Bernt, E., Gruber, W. Enzymatic determination of total cholesterol in serum. Z, Klin., Chem. Klin. Biochem., (1974). 12:226.

9. Tietz, N, W., ed. Fundamental of Clinical Chemistry, $3^{\text {rd }}$ Edition, Edited by W. B . Saunders, Phaliadelphia, PA. (1987).

10. Pinter EJ and Pattee CJ. Glucose and serum-triglycerides. Lancet, (1967). 2(7527):1205.

11. Walton H. M., B. Fingerhut and H. Miller Automated and Manual Direct Methods for the Determination of Blood Urea. Department of Pathology, State University of New York, Downstate Medical Center, and the Institute of Pathology, Kings County Hospital Center, Brooklyn, N. Y. 11203. (1965).

12. Gary L. Myers ,W. Greg Miller, Josef Coresh, James Fleming, Neil Greenberg and Tom Greene, (2005). Recommendations for Improving Serum Creatinine Measurement: A Report from the Laboratory Working Group of the National Kidney Disease Education Program. Published December 6, 2005. doi: 10.1373/clinchem. 2005.0525144, Clinical Chemistry. January 2006 vol. 52 no. 15-18.

13. Siekmann L., R. Bonora, C.A. Burtis, F. Ceriotti, P. Clerc-Renaud and G. Férard. IFCC primary reference procedures for the measurement of catalytic activity concentrations of enzymes at $37^{\circ} \mathrm{C}$ : Part 1 . The concept of reference procedures for the measurement of catalytic activity concentrations of enzymes. Clin. Chem. Lab. Med., (2002) 40: 631-634.

14. Witebsky, E., N.R. Rose, K. Terplan, J.R. Paine, R.W. Egan. Chronic thyroiditis and autoimmunization. J Am Med Assoc, (1957) 164: 1439-1447.

15. Elevitch, FR, Aronson, SB, Feichtmeir, T V, and Enterline, M L. Thin gel electrophoresis in agarose. Am. J. Clin. Pathol. (1966),46: 692-697.

16. Mainous AG; R Baker; RJ Koopman; S Saxena; VA
Diaz; CJ Everett; A Majeed. Diabetologia, (2007). 50: 934940.

17. Saxena M, Agrawal CG, Gautam S, Bid HK, Banerjee M. Overtdiabetic complications in obese type 2 diabetes mellitus patients from North India. Archives of Applied Science Research, (2009). 1: 57-66.

18. Bahathiq A. Relationship of leptin Hormones with Body Mass Index and waist Circumferences in Saudi Female population of the Makkah community. The Open Obesity Journal, (2010). 2: 95-100.

19. Thomas F; K Bean; B Pannier; JM Oppert; L Guize; A Benetos. Cardiovascular mortality in overweight subjects: the key role of associated risk factors. Hypertension, (2005), 46: 654-659.

20. Kasapoglu B, Turkay C, Bayram Y, Koca C. Role of GGT in diagnosis of metabolic syndrome: A clinic-based cross-sectional survey. Indian J Med Res, (2010),132: 56-61. 21. Jo SK, WY Lee, EJ Rhee. Serum gamma-glutamyl transferase activity predicts future development of metabolic syndrome defined by 2 different criteria. Clin Chim Acta. (2009) 403 (1-2): 234-240.

22. Perseghin G, P Scifo, F De Cobelli. Intramyocellular triglyceride content is a determinant of in vivo insulin resistance in humans: $1 \mathrm{H}-13 \mathrm{C}$ nuclear magnetic resonance spectroscopy assessment in offspring of type 2 diabetic parents. Diabetes. (1999), 48: 1600-1606.

23. Thamer C., J. Machann, O. Bachmann. Intramyocellular lipids: anthropometric determinants and relationships with maximal aerobic capacity and insulin sensitivity. $J$ Clin Endocrinol Metab. (2003), 88: 1785-1791.

24. Goodpaster B.H, Theriault R, S.C. Watkins. Intramuscular lipid content is increased in obesity and decreased by weight loss. Metabolism. (2000) 49: 467-472.

25. Palanisamy Pasupathi, Varatharaju Chandrasekar, Utharasamy Senthil Kumar. Diabetes \& Metabolic Syndrome: Clinical Research \& Reviews. (2009) 3 (3): 160-165. 26. Suzuki J, NannoM, Gemma R, Tanaka I, Taminato T, Yoshimi T. The mechanism of thyroid hormone abnormalities in patients with diabetes mellitus. Nippon Niabunpi Gakki Zasshi; (1994). 7: 465-70.

27. Kamble SM, Kamlakar PL, Vaidya S, Bambol VD. Influence of Coccinia indica on certain enzymes in glycolytic and lipolytic pathway in human diabetes. Indian J Med Sci, (1998). 52: 143-146.

28. Vizir OO. Activity of blood serum lactate dehydrogenase in diabetes mellitus. Probl Endokrinol (Mosk), (1977). 23(3):15-17. 